\title{
MULTIMODAL ANALYSIS ON ERTIGA CAR PRINT ADVERTISEMENT
}

\author{
Ridwin Purba* ${ }^{* 1}$, Herman ${ }^{* 2}$ \\ nridwinpurba@yahoo.com ${ }^{* 1}$, herman@uhn.ac.id ${ }^{* 2}$ \\ English Education Department*1,2 \\ University of Simalungun, Pematangsiantar, Indonesia*1, University of HKBP \\ Nommensen, Medan, Indonesia ${ }^{* 2}$
}

\begin{abstract}
This research is conducted to investigate the structure of print advertisement, Suzuki Ertiga car in multimodal analysis. Cheong (2004) explains the general structure of print advertisement is Capture ${ }^{\wedge}$ Focus ${ }^{\wedge}$ Justification. This structure covers the component of advertisement, namely verbal and visual. Theories to be used are Kress (2009) and Cheong (2004). Descriptive qualitative was conducted in this research. The source data was the advertisement of a car from Suzuki, Ertiga. After analyzing the data, the researchers found that verbal components (Announcement, Enhancer, Emblem, Tag, Cal-and-visit information) and visual components (Lead, Display and Emblem) were inserted in the advertisement of Ertiga. It means that the advertisement of Ertiga is made in a good way where the purpose of advertisement is to persuade the audience to buy the product. In short, the structures of the advertisement determine the quality of the product. To get a better understanding of Multimodal analysis for fulfilling human's needs in linguistics area, a more comprehensive analysis is needed in further research.
\end{abstract}

Keywords: Advertisement, multimodal analysis, verbal and visual components

DOI: https://doi.org/10.31943/wej.v4i1.77

\section{INTRODUCTION}

Advertisements are always consumed by people every day when they are watching television. Every day we are bombarded with global advertisements trying to sell us many kinds of living product, such as Coca-Cola, a car or Perhaps toothpaste. Whether they may be television commercials, Internet ads, posters or billboards, they are everywhere. Then what are the purpose? Why? Because consumers are everywhere and if a product can be sold everywhere, then why not advertise for it everywhere. But what happens when you need to advertise for a more narrow audience who are not everywhere and are not consumers, but prosumers and professionals? How do those companies convey their message and reach their audience. The way how advertisement can persuade viewers to be attracted is really important. How are those advertisement designed so the communicative purpose is delivered? We know that many products try to introduce their products through advertisement. Even though now we can see the promotion of the product is not via advertisement again, but some of them through 
inside the movie or film via the artist. Thus, the way they design the text, picture, symbols and relate them in a very proper way becomes important. Because the point of advertisement is how the reader or viewer is persuaded.

The quality of meaning sent by the advertisement to the viewers can be categorized in good, medium or bad. Some advertisement presented in verbal text, some of them used visual text and other can be both of them. A good print advertisement must contain verbal and visual components.

In relation to multimodal analysis. There are five five perspectives of multimodal analysis, they are social semiotic analysis (Kress \& van Leeuwen, 1996; van Leeuwen, 2005), systemic functional analysis (Baldry \& Thibault, 2006), social interaction (Norris, 2004), multimodal metaphor analysis (Forceville \& Urios-Aparisi, 2009) and multimodal text analysis from the perspective of corpus linguistics (Gu, 2006) (cited in Feng, Zhang \& O'Halloran, 2014, p. 89). This means that it has been developed over the past decade to systematically address much-debated questions about changes in society, for instance in relation to new media and technologies.

The media and technology then uses language to connect the writer and the reader/listener. The spoken and written language use can be understood more thoroughly if we take into account the fact that both forms very often are used with other modalities. The representation of language in the form of picture, symbols or text then become the essential point. It helps the creator to convey the meaning or the purpose so the message is delivered to those who see and read the text (multimodal text).

To meet the purpose of communication in multimodal text, this research is aimed to describe the structure of multimodal analysis found in the Ertiga car advertisement. Therefore, the researchers would like to use the Multimodal analysis theory by Cheong (2004) about verbal component (covers announcement, enhancer, emblem tag, call-and-visit-information) and visual component (covers lead, complement to the locus of attention, display, incongruent and emblem).

\section{LITERATURE REVIEW}

\section{Multimodal Analysis}

$\mathrm{Hu}$ and Luo (2016:32) as cited in Herman et.al (2019:36) stated that multimodal analysis is a relatively new subject for social semiotic research. Hence, Feng, Zhang, \& O'Halloran (2014) summarized five perspectives of multimodal analysis, they are social semiotic analysis (Kress \& van Leeuwen, 1996; van Leeuwen, 2005), systemic functional analysis (Baldry \& Thibault, 2006), social interaction (Norris, 2004), multimodal metaphor analysis (Forceville \& UriosAparisi, 2009) and multimodal text analysis from the perspective of corpus linguistics (Gu, 2006) (cited in Feng, Zhang \& O'Halloran, 2014, p. 89). This means that it has been developed over the past decade to systematically address much-debated questions about changes in society, for instance in relation to new media and technologies. Multimodal approaches have provided concepts, methods and a framework for the collection and analysis of visual, aural, embodied, and spatial aspects of interaction and environments, and the relationships between these. In the theory of LFS, text is any stretch of language use that is 'woven' 
together into a whole unit. In serving a particular purpose, a text is context dependent since the meanings within text can vary across situations of use and function. Since the contexts of situation where texts are found can overwhelmingly vary, it is useful to refer to Halliday and Hasan's (1985) in Butt (2000:3) point that when discussing text, we are discussing 'language that is functional in its context'.

It is essential to note that spoken and written language use can be understood more thoroughly if we take into account the fact that both forms very often are used with other modalities. Mode is the channel of meaning making resource that is shaped socially and understood culturally, for instance, writing, image, layout, music, gesture, speech, moving image, and soundtrack are common modes used in representation and communication (Kress, 2009:54). The functional use of language as text using more than one modality is termed a multimodal text. In written text, the multimodality feature is presented with several modes including visual images, design elements, and other semiotic resources (Jewitt and Kress, 2003 in Serafini, 2010).

\section{Multimodal Advertisement}

Advertising has developed into a kind of multimedia- assisted communication. It is increasingly dependent on multiple modes for effective promotion, thus using multimodality as one of its prominent features. Multimodality, a term borrowed fromKress notion of modes $(1997,2001)$, refers to the combination of different kinds of modes, visual, audio, written, oral, spatial, etc. in human communication (Kress and Leeuven 1996, Kress 2003) Multimodality in advertising suggests the use of different communicative modes in a single advertisement. For instance, a print advertisement uses a combination of words, illustration, font and color to send a message, and this mixing and melding of modalities represents multimodality. In communicating the messages and intentions of the advertisers, these varied. Yet integrated modes act interactively. The significance of visual modes in advertising has long been studied with great interest by scholars of advertising as well as from various other perspectives, including Psychology, consumer research, and marketing management. For instance, Claude Hopkins, a pioneer advertising consultant, stressed in his famous Scientific Advertising (1923:12), "Don't think that those millions will read your advertisements to find out if your product interests. They will decide by a glance-by your headline or your pictures." Hopkins' statement is particularly true in billboard advertising which usually shows large pictures and short headlines. Billboards are highly visible in top designated market areas because of their powerful presence. The headline in outdoor advertising such as Billboards, in contrast to its function in a newspaper or magazine advertisement which demonstrates the main content of the following body text, is like a caption in the way that it more often than not accompanies an illustration rather than other verbal text. Viewed from the cognitive perspective, the headline, or slogan as it is most commonly called, is the linguistic element and acts as the most explicit mode of communication . It is generally in dispensable in driving people into the action of purchase, no matter how many modes are deployed in an advertisement. Headlines are thus vital for 
the success of advertisements. Even so, both advertising- focused and cognition oriented studies have revealed that the various non- verbal elements in different advertising media are also crucial for the interpretation of the verbal message, mainly because multimodal advertisements have been designed to facilitate an interaction between the different kinds of modes involved in communication for the best possible advertising effect. The headline and the accompanying illustration interact with each other and make the message conveyed in the billboard more explicit. However, in Translation studies, only a few scholars have given attention to this neglect in the study of he role of non-verbal modes in advertisement translation.

Multimodal text analysis has become a crucial part of research, teaching and practice for a wide range of academic and practical disciplines. A variety of techniques, theoretical frameworks and methodologies have therefore evolved for such analysis. For linguists, in particular, concerned with accounting for the communication of meaning within texts, issues arising from the consideration of semiotic resources other than language, in interaction with each other and with language such as gesture, gaze, proximics, dress, visual and aural art, image text relation and page layout, cinematographic and sound design and production resources, etc have emerged in recent decades as important challenges. Meanwhile, the emergence of multimodal studies as a distinct area of study in linguistics has also revealed a range of issues specifically relevant to the multimodal text analyst.

Hasan (1996: 41) in Cheong (2004: 164) explains the general structure of print advertisement is Capture ${ }^{\wedge}$ Focus ${ }^{\wedge}$ Justification. This structure tries to explain the component of advertisement wholefully, verbal and visual. In the next development, because of this structure is valued unclear in seeing the relationship between the component of visual and verbal, so that Cheong (2004: 165 - 174) gives explanation more clearly about the structure of printed advertisement in figure:

Table.1 The General Structure Printed Advertisement

\begin{tabular}{ll}
\hline Verbal Component & Visual Component \\
\hline Announcement: Primary, Secondary & $\begin{array}{l}\text { Lead: Locus of Attention (LoA), } \\
\text { Complement to the Locus of Attention } \\
\text { (Comp. LoA) } \\
\text { Display: Explicit, Implicit, Congruent, } \\
\text { Incongruent (metaphorical) } \\
\text { Enhancer }\end{array}$ \\
Emblem & \\
Tag & \\
Call-and-visit information
\end{tabular}

\section{RESEARCH METHODOLOGY \\ Research Design}


This research used a qualitative approach. A qualitative approach is used to describe the data. One of the characteristics of the qualitative method is to see the process we have to deal with according to the setting; the place where the research will be carried out. (Bogdan and Biklen, 1998:4-7) The research is to describe printed advertisement text which reveals verbal and non verbal language.

\section{Data Collection Technique}

There are some steps in collecting the data, they are:

1. Browsing google

2. Searching the print advertisement from car

3. Downloading the print advertisement which is taken from google image results website, https://www.google.co.id/search?q=iklan+mobil+suzuki+ertiga\&rlz=1C1 AOHY_enID708ID708\&espv $=2 \& b i w=1280 \& b i h=709 \&$ source $=\operatorname{lnms}$ \&tbm=isch\&sa=X\&ved=0ahUKEwiwk7HA28PPAhVGL48KHa1EA 5kQ_AUIBigB\#imgrc=KJN3eR9iI6RiLM\%3A (see the picture 1)

4. Saving the print advertisement to the folder

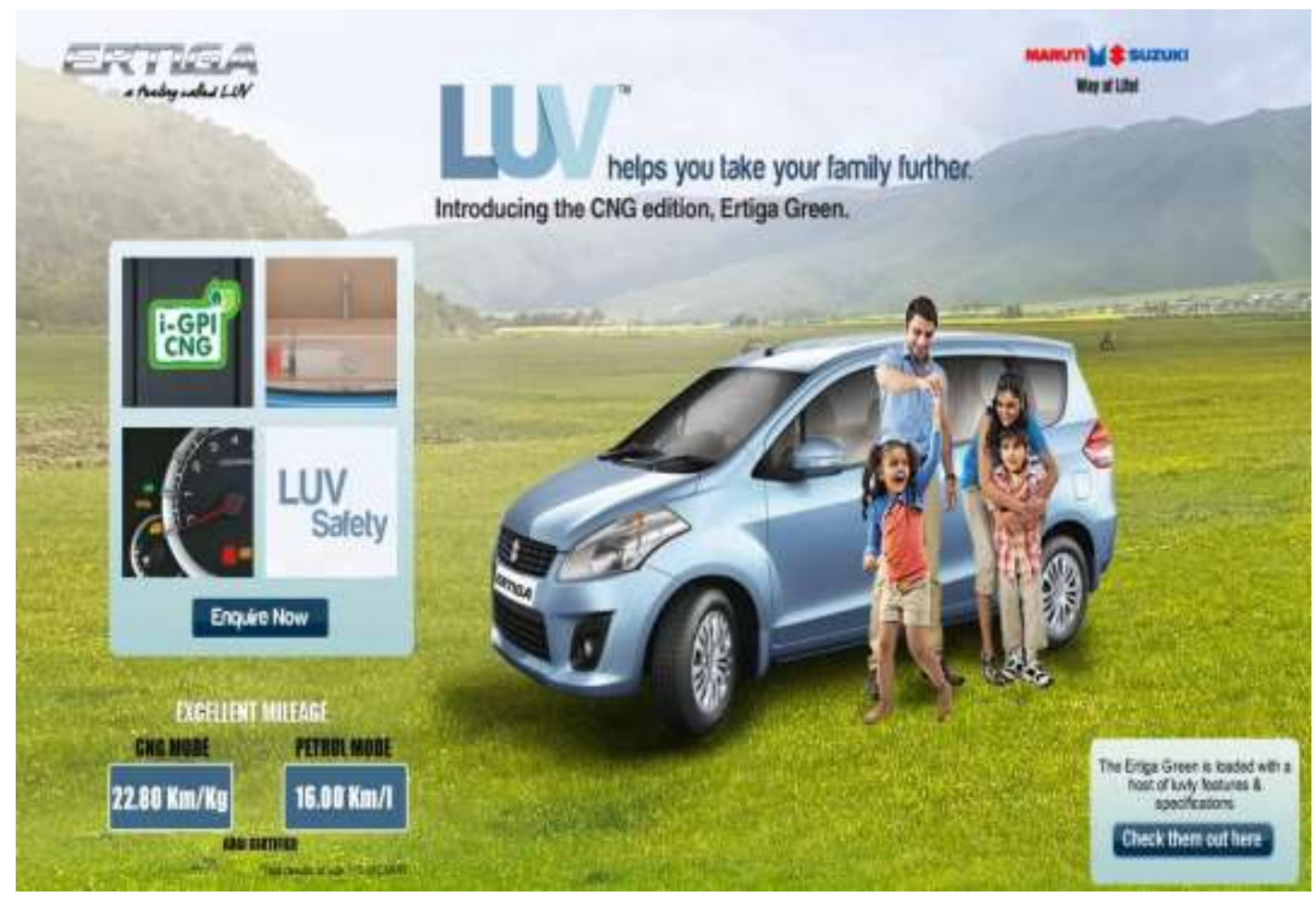

Picture 1

\section{Data Analysis Technique}

In analyzing the data, descriptive qualitative is used. This method is used to have a problem solving procedure which is researched by describing the subject or object of the research based on the real fact 
nowadays. So, the following procedures are followed to carry out this Multimodal analysis on Ertiga car.

a) Searching and taking the print advertisement of Ertiga car from google image result

b) Reading the text and trying to analyze the advertisement.

c) Classifying and analyzing the data (advertisement) to the verbal component and visual component which are presented by theory of Cheong (2004).

d) Then drawing the conclusion.

\section{FINDING AND DISCUSSION}

After analyzing the data above, the researcher came to the finding. The finding was all components, visual and verbal, were depicted in the advertisement of Suzuki Ertiga Car which covers verbal components (Announcement, Enhancer, Emblem, Tag, Cal-and-visit information) and visual components (Lead, Display and Emblem). The detail discussion of the finding was discussed in the following point (Picture 2).

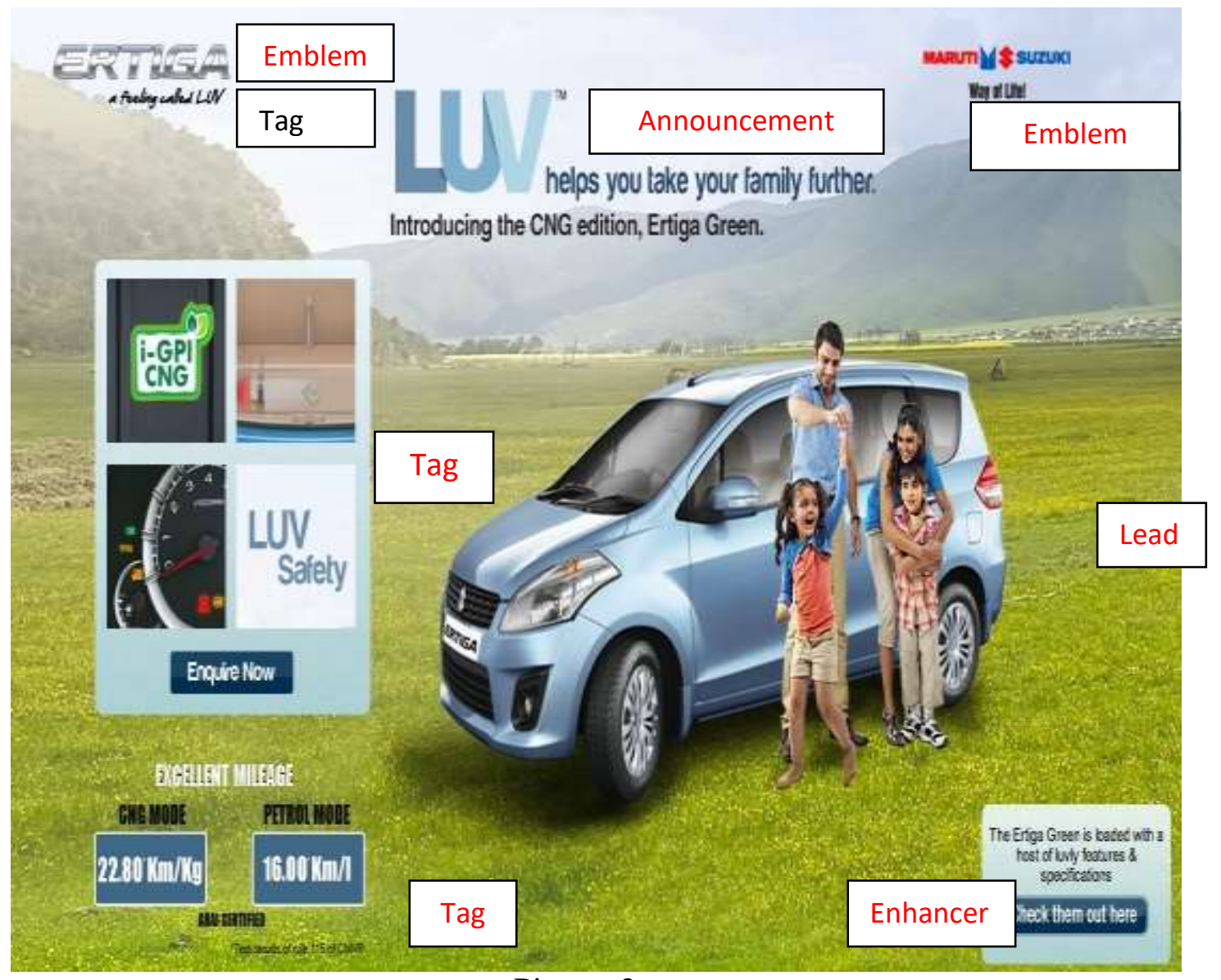

Picture 2 
Cheong's theory(2004) stated that advertisement has its own structure that covers structure of verbal components (Announcement, Enhancer, Emblem, Tag, Cal-and-visit information) and visual components (Lead, Display and Emblem) are inserted in the advertisement.

\begin{tabular}{|l|l|}
\hline VISUAL COMPONENTS & $\begin{array}{l}\text { Lead } \\
\text { Locus of Attention (LoA) } \\
\text { Complement of LoA } \\
\text { Display: Explicit/Implicit, Congruent/Incongruent } \\
\text { Emblem: Logo of the product }\end{array}$ \\
\hline VERBAL & $\begin{array}{l}\text { Announcement: Primary, Secondary1, Secondary } \\
2 \\
\text { Enhancer (usually in paragraph form) } \\
\text { Emblem } \\
\text { Tag (information not included in the enhancer) } \\
\text { Call and visit information }\end{array}$ \\
\hline
\end{tabular}

\section{ANNOUNCEMENT}

In a print advertisement, the most Salient linguistic item $/ \mathrm{s}$ are termed the Announcement. The Announcement has Relative Prominence in Scale and Colour, Font and Size. Ideationally, the Announcement captures and conveys the essence of an intended message the advertisers wish to foreground to the consumers as shown in the advertisement. This announcement is to attract people to buy the product by stating that this car is suitable for family and introducing the CNG (Compressed Natural Gas).

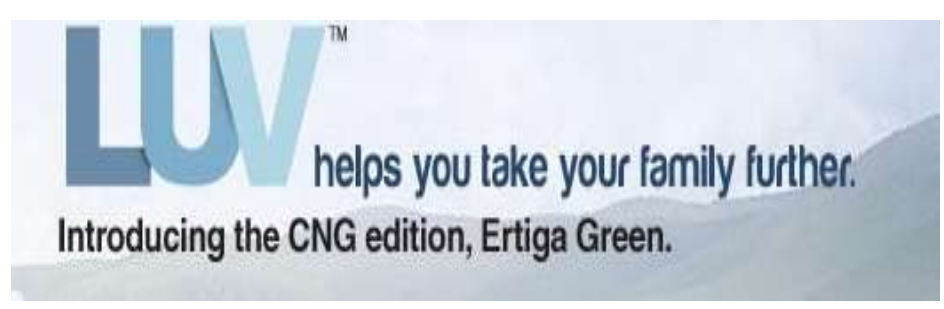

\section{LEAD}

Picture 3

The Lead is thus termed as it is Interpersonally most Salient (Kress and van Leeuwen, 1996) through choices in size, position and/or colour. The Lead has a wide spectrum in terms of meaning potential, that is, many possible meanings emanate from the Lead. Interpreted independently of the Announcement, Enhancer, Display and Emblem, the Lead is figuratively an efflorescence of meaning. For example, the car, family and mountain could be calling to attract people of buying the product. Therefore, on its own, the Lead has a bounty or a kaleidoscope of possible meanings.

\section{ENHANCER}

The Enhancer comprises linguistic items only, usually in paragraph form, as exemplified by the labelled advertisements above as: 


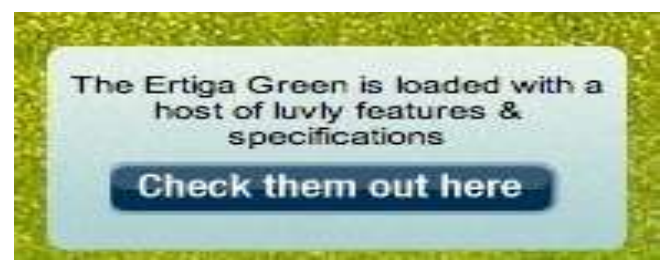

Picture 4

The Enhancer builds on or modifies the meaning emanating from the interaction between the Lead and the Announcement. Interpersonally, its function is to persuade and influence viewers to purchase the product, thus the Enhancer contains Interpersonal lexis (in bold print below), which carry an attitudinal and/or affective thrust. Through Interpersonal lexis, 'texts/speakers attach an intersubjective value or assessment to participants and processes by reference to emotional responses or to systems of culturally-determined value systems' (White, 1999). Ideationally, it details the advertisers' reasoning/argument as to why the product is worth the customers' attention and money, and so Logical relations and rankshifted clauses are evident. The Tag is usually in the form of one-liners in small print and is typically non-Salient as illustrated in preceding labelled advertisements. Grammatically, Tags are usually realized as non-finite, for example, Luv Safety and Excellence Milliage. Grammatically, there could be exceptions to the above but it is not within the scope of this paper to explore the lexicogrammatical realizations of Tags. As can be seen in the preceding labelled advertisements, the Call-and-Visit Information is usually in small print and nonsalient, comprising contact information as to where, when, how the product/service is available to the consumer.

\section{EMBLEM}

The Emblem may be realized visually as the logo of the product/service advertised and its linguistic realization is in the form of the brandname of the product/service. Ideationally and ideologically, it is the stamp of authority bespeaking and validating the authenticity of the product advertised. The Emblem functions to bestow an identity, as well as to confer status to a product. The Emblem may be positioned anywhere in the advertisement. However, it is interpersonally Salient to capture attention. The Emblem in the advertisement is the logo of ERTIGA a feeling called luv and MARUTI SUZUKI way of life

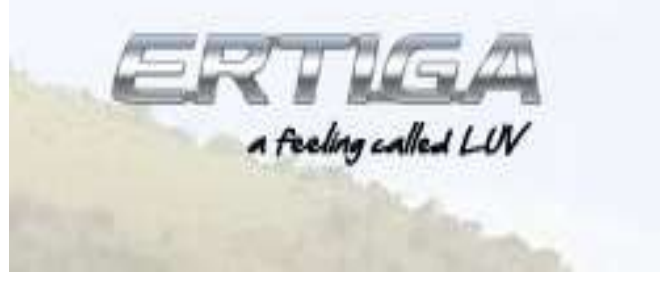




\section{Picture 5}

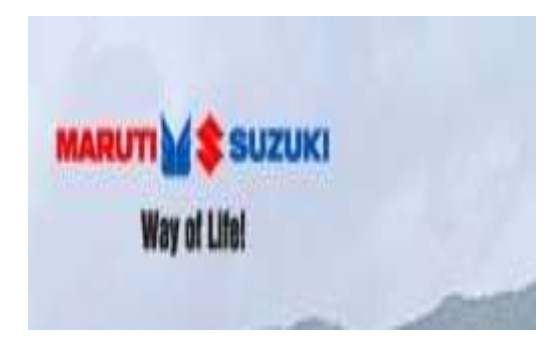

Picture 6

TAG

Tag is a recommendation which is given by the advertisement where we can see two recommendations. One is that Ertiga car is having excellent mileage and on the other hand it gives safety.

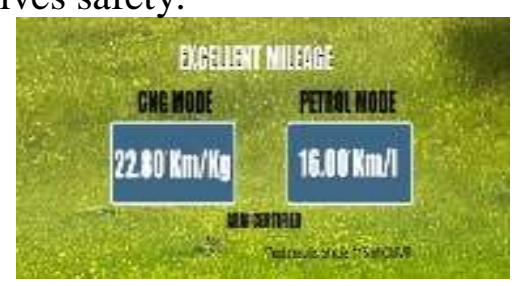

Picture 7

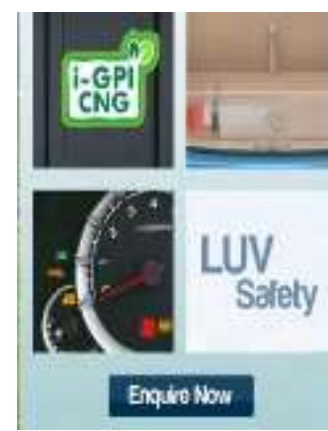

Picture 8

After analyzing the data based on the theory of Cheong (2004), the researcher found that the structure of verbal components (Announcement, Enhancer, Emblem, Tag, Cal-and-visit information) and visual components (Lead, Display and Emblem) are inserted in the advertisement. Here, the researchers emphasize that Cheong's theory about Generic Structure of Potential of print advertisement is an obligatory.

After analyzing the data based on the theory of Cheong (2004) to the structure of print advertisement, the researchers would like to discuss that all the structures of the print advertisement were found in the print advertisement of Ertiga Car advertisement. The structures were Announcement, Enhancer, Emblem, Tag, Cal-and-visit information in the verbal components and visual 
components which covered Lead, Display and Emblem. Based on the finding in this research, the researcher assumed that there was a similarity between the result of the research done by Lubis and Sinar (2014) in their research entitled the structure of selected print advertisement: A multimodal analysis. The advertisement was "New Pond's Nourishing System", New Dove Flawless White". The theory used was the same by Cheong's theory (2004) about the structures of print advertisement. But the difference lies on the combination theory that Lubis and Sinar use. Beside the print advertisement was analyzed through the multimodal analysis theory (Cheong, 2004), they also used the theory of metafunction analysis by Halliday $(1985,1994,2004)$ which covered ideational: transitivity, interpersonal: modus system, and textual: theme-rheme. The research found that every component of the metafunction has the same potential in expressing about genre. Visual and verbal text in this case has a relationship of additive, consequential. Genre which is expressed by the advertisement text is based on two ideology includes in the text, they are: seixis ideology and the ideology that assumes the similarity of man and woman.

\section{CONCLUSION}

After describing the theory of Multimodal Analysis by Cheong (2004), then classifying and analyzing them into the Ertiga car advertisement, it can be concluded that structure of components potential print advertisement are used in the advertisement, they are visual components cover Lead, Display and Emblem; and verbal components cover Announcement, Enhancer, Emblem, Tag, Cal-andvisit information. The researchers hope for the government that they can promote our country through the advertisement better by using the verbal and visual components, especially promoting the tourism so that people can come to Indonesia and make Indonesia become better and better in the future. last but not least, the researchers hope that more research about Multimodal Analysis needs to be conducted to make further analysis in other kinds of field, in order to get a better understanding of Multimodal analysis for fulfilling human's needs in linguistics area.

\section{REFERENCES}

Butt, D. (2000). Using functional grammar: An explorer's guide. Sydney: National Centre for Language Teaching and Research, Macquarie University

Cheong, Y. Y., (2004). The construal of ideational meaning in print advertisement. In K. L. O’Halloran (Ed.) Multimodal discourse analysis: Systemic functional perspective. London: Continuum, p. 163-195

Cheong, Y. Y. (2004). Open linguistics series: The construal of ideational meaning in print advertisements (Edited by Kal L. O'Halloran). London and New York: Continuum. 
Febrianti, Y. (2013). Multimodal discourse analysis in Indonesian advertisements. The $7^{\text {th }}$ International Seminar, Satya Wacana Christian University. Language Policy and Planning: What are the Issues?, November 20-21, 2013, UKSW

Feng, D., Zhang, D., \& O'Halloran, K. (2014). Advances and frontiers of multimodal discourse analysis.Contemporary Linguistics, 16(1), 88-99.

Herman, Murni, S.M., Sibarani, B., Saragih, A. (2019). Structures of Representational Metafunctions of the "Cheng Beng" Ceremony in Pematangsiantar: A Multimodal Analysis. International Journal of Innovation, Creativity and Change, 8(4), 34-46. Available at: https://www.ijicc.net/images/vol8iss4/8403_Herman_2019_E_R.pdf

Hu, C and Luo, M. (2016).A social semiotic analysis of air France's print advertisements. International Journal of English Linguistics; Vol. 6, No. 4; 2016. Canadian Center of Science and Education.

Janks, H. (1997). Critical discourse analysis as a research tool. Discourse: Studies in the cultural politics of education, 18(3):329-341

Jewitt, C. (2009). An introduction to multimodality. In Carey Jewitt (Ed). The Routledge Handbook of Multimodal Analysis. London: Routledge, p. 1427

Jewitt, C. (2009). Different approaches to multimodality. In Carey Jewitt (Ed). The Routledge Handbook of Multimodal Analysis. London: Routledge, p. 28-39

Kress, G. (2009). What is mode? In Carey Jewitt (Ed). The Routledge handbook of Multimodal Analysis. London: Routledge, p. 54-67

Lubis, D. S. and Sinar, T. S. (2014). The structure of selected print advertisement: A multimodal analysis. Kajian Linguistik, Februari 2014, PP. 161-177 Copyright (C2014, Program Studi Linguistik FIB USU, ISSN 1693-4660

Machin, D. (2009). Multimodality and theories of the visual. In Carey Jewitt (Ed). The Routledge Handbook of Multimodal Analysis. London: Routledge, p. $181-190$

Mahsun. (2007). Metode penelitian bahasa. Jakarta: PT. Raja Grafindo Persada

Martin, J.R., \& Rose, D. (2003). Working with discourse: Meaning beyond the clause. London, New York: Continuum

O'Halloran, K.L. (2008). Systemic functional-multimodal discourse analysis (SFMDA): Constructing ideational meaning using language and visual imagery. London: Sage Publications. Retrieved August 12, 2010 from University of Adelaide library database 
Wiralodra English Journal (WEJ)

Vol 4 No 1 Maret 2020

O'Toole, M. (1994). The language of displayed art. London: Leicester University Press.

Serafini, F. (2010). Reading multimodal texts: Perceptual, structural, and ideological perspective. Children's Literature in Education (2010) 41:85-104 